\title{
O processo de expansão urbana e seus impactos na Estação Ecológica de Ribeirão Preto, SP
}

The urban sprawl process and its impacts on the Ecological Station of Ribeirão Preto, SP, Brazil

\section{Emanoele Lima Abreu I; Sammy Dutra Saquy II; Pedro Henrique de Godoy Fernandes III; Silvia Cristina de Jesus IV; Adriana Maria Zalla Catoj v}

\section{RESUMO}

Embora os instrumentos normativos de planejamento urbano incluam a avaliação de impacto ambiental, há uma flexibilização dessas leis devido a interesses públicos e privados que têm objetivos contrários às políticas ambientais. No município de Ribeirão Preto, a produção de café e cana-de-açúcar tem contribuído para a fragmentação da vegetação nativa, reduzida a $6 \%$ da área municipal (4.200 ha). A Estação Ecológica de Ribeirão Preto (EERP) é o maior remanescente nativo (155 ha) e sofre pressões por estar localizada no meio urbano. Este trabalho investigou a pressão urbana na Zona de Amortecimento (ZA) e sua relação com as mudanças no Plano Diretor (PD) e leis complementares. Os mapas de cobertura da terra (2010 e 2017) também foram analisados com o objetivo de quantificar a conversão de florestas nativas para usos antrópicos, mostrando uma intensa expansão urbana na ZA no período analisado. Por outro lado, a legislação urbanística-ambiental municipal evoluiu, visto que a MP anterior (datada de 1995) abordou o meio ambiente de maneira específica mas foi modificada na lei de 2018, que tenta integrar o zoneamento urbano à zona de amortecimento a fim de tornar o uso do solo compatível com o Plano de Manejo da EERP.

Palavras-chave: Unidades de Conservação; Zona de Amortecimento; Mapeamento do Uso e Ocupação das Terras; Planejamento Urbano; Plano Diretor

\footnotetext{
I Universidade Federal de São Carlos, São Carlos, Brazil. emanoelelimaabreu@gmail.com

II Universidade Federal de São Carlos, São Carlos, Brazil. sammysaquy@gmail.com

III Universidade Federal de São Carlos, São Carlos, Brazil. Fernandes.phg@gmail.com

Iv Universidade Federal de São Carlos, São Carlos, Brazil. silviacrisj@gmail.com

v Universidade Federal de São Carlos, São Carlos, Brazil. catojo@gmail.com
} 


\section{ABSTRACT}

Although the normative instruments of urban planning include the environmental impact assessment, there is a loosening of these laws due to public and private interests that have purposes contrary to environmental policies. In the municipality of Ribeirão Preto, coffee and sugarcane monocultures have contributed to the fragmentation of native vegetation, reducing it to $6 \%$ of the municipal area (4,200 ha). The Ecological Station of Ribeirão Preto (ESRP) is the larger native remnant (155 ha) and suffers pressures for being located in the urban environment. This work investigated the urban pressure in the Buffer Zone (BZ) and its relation to the changes in the Master Plan (MP) and complementary laws. The land cover maps (2010 and 2017) were also analyzed in order to quantify the conversion of native forests to anthropic uses, showing an intense urban expansion in the BZ over the period analyzed. On the other hand, municipal urban environmental legislation has evolved seeing that the previous MP (dated from 1995) approached the environment in a very specific way, which was modified in the 2018 law, which attempts to integrate the urban zoning to the buffer zone in order to make land use compatible with the ESRP Management Plan.

Keywords: Conservation Units; Protected Areas; Buffer Zone; Land Use and Land Cover Mapping; Urban Planning; Master Plan

\section{INTRODUÇÃO}

Os gradativos processos de crescimento e urbanização das cidades, apoiados na lógica de mercantilização e financeirização do espaço urbano, têm ocasionado diversas pressões sobre os ambientes naturais. Apesar de já existirem instrumentos normativos que visam inserir a avaliação dos impactos ambientais no planejamento urbano, via de regra esses são flexibilizados e negligenciados, sob argumentos de interesse público e pressões externas, que muitas vezes possuem objetivos contrários à salvaguarda ambiental (HARVEY, 2014; ROLNIK, 2015).

O processo de urbanização envolve a transformação de ambientes naturais para atender necessidades do modo de vida da sociedade contemporânea, que interferem diretamente na qualidade e quantidade de seus recursos de acordo com a necessidade da expansão urbana. Dessa forma, predominam-se os aspectos econômicos em detrimento 
dos sociais e ambientais (SALLES; GRIGIO; SILVA, 2013). Nessa lógica, além da alteração na paisagem, observa-se a segregação dos espaços e um crescente deslocamento das classes médias e altas para empreendimentos imobiliários mais distantes do centro e ainda pouco urbanizados, que anteriormente correspondiam a uma área com vegetação nativa, destruindo paisagens e comprometendo a biodiversidade local (GOULART; BENTO, 2011; PARFITT, 2016).

Para disciplinar esse processo de expansão urbana de maneira que também atenda os interesses da conservação ambiental, as legislações ambiental e urbana precisam se articular e, apesar de já haver uma evolução nesse sentido, ainda há necessidade de melhorias para amenizar os conflitos gerados por interesses do mercado e outros atores (COSTA; PEIXOTO, 2007).

A temática ambiental não foi incorporada no campo da gestão urbana brasileira até meados dos anos 1990, presente nos planos diretores apenas de forma setorial. Em 2001, com a aprovação da Lei Federal no 10.257, que instituiu o Estatuto da Cidade (EC), a dimensão ambiental foi consolidada como um importante elemento para o planejamento urbano, porém encontrou pouco amparo nos instrumentos instituídos, mais direcionados ao enfrentamento da especulação imobiliária, sendo o Estudo de Impacto de Vizinhança (EIV) mais próximo dos instrumentos ambientais (PERES; SILVA, 2013). A articulação do EIV aos processos de licenciamento urbanístico e ambiental vem sendo apontado como um caminho para a integração e aprimoramento da gestão municipal e melhoria da qualidade ambiental das cidades (PERES; CASSIANO, 2019).

Diversos instrumentos de planejamento urbano foram publicados pelo Estatuto da Cidade, porém o Plano Diretor (PD) é reconhecidamente um dos mais importantes. Fruto de um processo político participativo e dinâmico, o PD tem como objetivo mobilizar todos os seguimentos sociais para debater e construir um pacto sobre o projeto de desenvolvimento do município (ROLNIK et al, 2004). De acordo com o EC, a propriedade urbana cumpre sua função social quando atende às exigências fundamentais de ordenação da cidade expressas no Plano Diretor, principal lei do município que trata da ocupação e organização do seu território. Muito municípios optam por construir seu PD através de uma lei única, enquanto outros o dividem em Planos Diretores Setoriais, voltados para diferentes temáticas voltadas ao ordenamento territorial: Plano Diretor de Gestão das Águas, de Resíduos Sólidos, da Qualidade do Ar e de Arborização Urbana (NESPOLO et al, 2020). 
Mesmo havendo nos Planos Diretores (PD), e nas suas leis complementares, a delimitação de áreas a serem preservadas, apenas a criação dessas legislações não tem se mostrado suficiente para garantir a proteção desses espaços. Com isso surge a necessidade de implementar instrumentos de planejamento e gestão, como, por exemplo, o Licenciamento e Ambiental (LA) e o EIV, com o objetivo de disciplinar a expansão urbana de maneira integrada com a conservação ambiental (PARFITT, 2016). A consolidação desses instrumentos requer que sua existência seja prevista no planejamento urbano e, além disso, que a sua salvaguarda jurídica seja efetivada por meio de um arcabouço legal (KUDO, 2016).

A Estação Ecológica de Ribeirão Preto (EERP) se encontra em local que sofre diferentes pressões (urbanas e rurais) que podem gerar impactos negativos para a Unidade de Conservação (UC), sobretudo em sua Zona de Amortecimento (ZA). Muitas vezes as áreas urbanas que envolvem Unidades de Conservação são vistas pelo setor imobiliário como entraves para o desenvolvimento local (ABREU et al, 2019). Com isso, o entendimento da gestão ambiental e urbana municipal, bem como as legislações que regem e norteiam o planejamento urbano no município, são necessários para se buscar maior conservação da biodiversidade em UC tão próximas a áreas urbanas. Com o objetivo analisar a pressão antrópica urbana sobre ZA da EERP, realizou-se: 0 mapeamento do uso e ocupação do solo na ZA e no seu entorno; a análise e comparação do conteúdo do Plano de Manejo da unidade e do Plano Diretor do município; e a análise de avanços e retrocessos na revisão do PD relacionados às questões ambientais.

\section{METODOLOGIA}

\subsection{Caracterização do município de Ribeirão Preto e da área de estudo}

O município de Ribeirão Preto está localizado no estado de São Paulo (Figura 1) e possui uma população estimada em 604.682 habitantes em uma área de 651 km² e PIB per capita de $\mathrm{R} \$ 41.736$ (IBGE, 2010). A região foi um importante centro produtor de café no final do século XIX e início do século XX e, posteriormente, de cana-de-açúcar, a partir da segunda metade do século XX (VARANDA et al., 2015).

A ERRP foi criada em 1957 como Reserva Estadual Florestal e transformada em Estação Ecológica em 1984; também conhecida como Mata de Santa Tereza, é uma Unidade de Conservação do grupo de Proteção Integral e conta uma área de 154 
hectares, com mais de 300 espécies inventariadas, entre fauna e flora, algumas ameaçadas de extinção, de acordo com o Plano de Manejo da unidade (SÃO PAULO, 2010).

Figura 1 - Localização da área de estudo

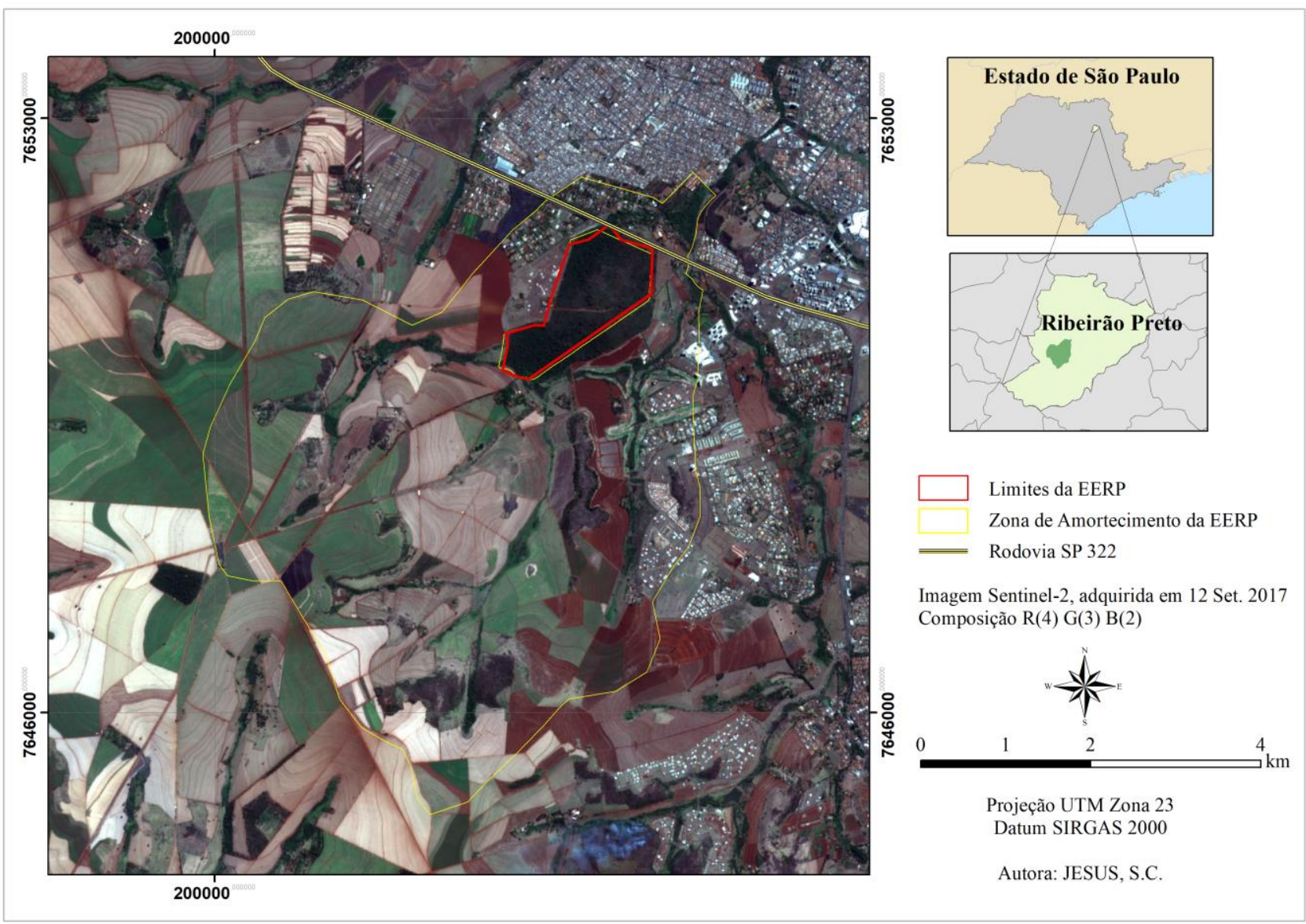

\subsection{Mapeamento da Estação Ecológica de Ribeirão Preto}

Foram analisados os quantitativos das classes de uso das terras a partir do Projeto de Mapeamento Anual da Cobertura e Uso do Solo do Brasil (MAPBIOMAS, 2018), considerando o ano de 2017, coleção 3.0. São mapas anuais de cobertura da terra gerados a partir de imagens da coleção Landsat, com acurácia de 75\%.

Os dados foram adquiridos a partir das ferramentas do MapBiomas disponíveis na plataforma Google Earth Engine. Os dados temáticos foram vetorizados e sua área foi calculada considerando a projeção SIRGAS 2000 / UTM zone 23S no software ArcGIS versão 10.5. Às classes de cobertura da terra foi atribuída a legenda de cores conforme o Manual Técnico de Uso da Terra do IBGE (2013). 
Os limites da EERP e da sua zona de amortecimento foram disponibilizados pela Fundação para a Conservação e a Produção Florestal do Estado de São Paulo / Fundação Florestal, por meio do Plano de Manejo da Unidade (SÃO PAULO, 2010).

\subsection{Análise documental}

A pesquisa documental compreende uma profunda e vasta análise de diversos arquivos que ainda não passaram por processo de investigação, ou que possam ser novamente avaliados, pesquisando-se outras perspectivas ou dados adicionais, chamados de documentos. Dessa forma, a pesquisa documental consiste em informações provenientes de documentos, com o propósito de extrair dados contidos neles, a fim de compreender um processo ou fenômeno (KRIPKA et al., 2015)

O Plano Diretor do município de Ribeirão Preto e suas respectivas revisões e leis complementares foram examinados, buscando-se informações acerca da Estação Ecológica de Ribeirão Preto e do seu entorno (KRIPKA et al., 2015). O conteúdo do Plano de Manejo da unidade também foi analisado, buscando sobretudo informações sobre a Zona de Amortecimento e tipologias de atividades e empreendimentos permitidos nessa área.

\section{REFERENCIAL TEÓRICO}

O modelo de criação de áreas naturais protegidas, instituído nos Estados Unidos no século XIX, constitui uma das políticas conservacionistas mais utilizadas nos países em desenvolvimento. Esse paradigma foi transposto para o Brasil, que apresenta contextos ecológico, social e cultural distintos dos EUA, ocasionando diversos conflitos com as populações tradicionais pioneiramente residentes nessas áreas (DIEGUES, 1996).

Por volta da década de 1930 foram verificados os primeiros impulsos para a regulamentação da posse dos recursos naturais em âmbito nacional, com o objetivo de atender à crescente demanda gerada pela urbanização e industrialização das cidades brasileiras. Também durante esse período foi criada a maioria dos dispositivos legais que dariam, posteriormente, suporte à criação de áreas protegidas no Brasil, como o Código Florestal, Código de Mineração e Código de Águas, todos do ano de 1934 (PECCATIELLO, 2011). Também na mesma década foram criados os três primeiros parques nacionais: Itatiaia em 1937 e Iguaçu e Serra dos Órgãos em 1939. 
Um novo Código Florestal foi promulgado por meio da Lei no 4.771/1965 (atualmente revogado pela Lei no 2.651/2012) e centralizou quase todo o controle da exploração florestal no âmbito federal e o Instituto Brasileiro de Desenvolvimento Florestal (IBDF), criado em 1967, viria a absorver os principais encargos nesse sentido. Passou a ser competência desse órgão o controle de quase toda questão florestal no país e a administração das áreas protegidas de propriedade da União. A Secretaria Especial de Meio Ambiente (Sema), instituída em 1973, tinha como função controlar a poluição e a degradação ambiental, mas possuía uma série de conflitos de competências com o IBDF, como ações de preservação de espécies animais e vegetais ameaçados de extinção.

A homologação do Sistema Nacional de Unidade de Conservação (SNUC), publicado pela Lei Federal no 9.985/2000, foi precedida de uma série de outras importantes legislações ambientais, como a Política Nacional de Meio Ambiente (Lei no 6.938/1981). Esse importante ganho para a conservação da biodiversidade no território brasileiro ocorreu em meio a um grande confronto entre posições distintas, algumas incompatíveis, representadas pelos ruralistas, preservacionistas, ambientalistas, conservacionistas, entre outros (PECCATIELLO, 2011).

Independentemente da categoria em que se enquadra uma UC criada dentro de área urbana, esta poderá proporcionar a melhoria da qualidade de vida dos cidadãos, bem como poderá constituir um instrumento para o planejamento do município (MAZZEI; COLESANTI; SANTOS, 2007). Porém, segundo Brito (2008), muitos conflitos que envolvem desde a criação até a gestão dessas unidades têm se intensificado devido à complexidade e os diferentes interesses e objetivos que essas áreas possuem e que foram se diversificando ao longo do tempo, tornando cada vez mais complexas as discussões sobre o tema.

Gomes, Carmo e Santos (2004), em estudo em que analisaram os conflitos que envolvem as Unidades de Conservação no município de Paraty, afirmaram que muitas vezes essas áreas são vistas, principalmente pelo setor imobiliário, como entraves para o desenvolvimento local e mostram que somente a criação de legislações que norteiam o assunto não são suficientes. Segundo os autores, isso torna imprescindível que a gestão ambiental consiga intermediar esses conflitos e conciliar o desenvolvimento e a conservação dessas unidades. Corroborando essa afirmação, Benjamin (2001) declara que é necessário muito mais que uma legislação formal para instalar um efetivo Sistema Nacional de Unidades de Conservação no Brasil. A lei do SNUC indica que a jornada nesse âmbito está apenas começando. 
O entorno das Unidades de Conservação é o local onde as pressões antrópicas, oriundas de diversas atividades, podem influenciar de maneira mais significativa e com maior frequência o objetivo da conservação de áreas naturais e por isso é indispensável que se considere o manejo das áreas circunvizinhas. Para isso, a Zona de Amortecimento, como instrumento de planejamento territorial, possui a função de estabelecer diretrizes para disciplinar o uso das áreas no entorno das unidades (BEIROZ, 2015; BRASIL, 2000).

As Zonas de Amortecimento devem ter um planejamento correto no processo de sua implementação pois é de grande importância que estas sejam tratadas como uma questão prioritária para a gestão das unidades. No interior do estado de São Paulo, a atenção para as Zonas de Amortecimento merece um destaque maior por sofrerem grande pressão na mudança da paisagem e ameaça à biodiversidade devido à cultura de cana de açúcar (MORAES; MELLO; TOPPA, 2015).

Kotchetkoff-Henriques et al. (2005) caracterizam essa pequena parcela da vegetação natural remanescente no município de Ribeirão Preto como vegetação de Cerrado e Mata Atlântica, distribuída em vários fragmentos na seguinte proporção:

As matas mesófilas semidecíduas atualmente ocupam apenas 1,4\% do município ( $35,2 \%$ da vegetação natural atual). Os cerrados hoje estão reduzidos a $0,8 \%$ da área do município ( $21,3 \%$ da vegetação natural atual). As matas paludícolas estão reduzidas a $0,6 \%$ da área do município e a $16,4 \%$ da vegetação natural atual. As matas decíduas hoje estão reduzidas a $1,1 \%$ da área do município e a $27,1 \%$ da vegetação natural atual.

\section{RESULTADOS E DISCUSSÃo}

\subsection{Mapeamento e zoneamento do entorno da Estação Ecológica de Ribeirão Preto}

O Plano de Manejo da EERP foi elaborado como um dos componentes do Termo de Compromisso e Compensação Ambiental (TCCA) do processo SMA $n^{\circ}$ 13.686/1998, relativo ao licenciamento ambiental em nível estadual da implantação de um empreendimento pela Degussa Brasil Ltda.

De acordo com o Artigo $36 \S 3^{\circ}$ do SNUC:

Quando o empreendimento afetar unidade de conservação específica ou sua zona de amortecimento, o licenciamento a que se refere o caput deste artigo só poderá ser concedido mediante autorização do órgão responsável por sua administração, e a unidade afetada, mesmo que não pertencente ao Grupo de Proteção Integral, deverá ser uma das beneficiárias da compensação definida neste artigo. 
O Plano de Manejo (PM) da unidade foi organizado após consistentes diagnósticos e estudos sobre os meios físico, biótico e antrópico da unidade. Tem como objetivo estabelecer as normas, restrições e ações a serem desenvolvidas dentro da unidade, o manejo da biodiversidade, a criação de corredores ecológicos, visitação e a implantação de infraestruturas dentro da Estação Ecológica. Nesse documento são apontados o desenvolvimento econômico da cidade de Ribeirão Preto, a expansão da malha urbana e a pressão sobre a biodiversidade da unidade. Um dos desafios a serem transpostos, de acordo com o plano, é a redução da pressão imobiliária no entorno da Estação Ecológica e a recuperação das áreas degradadas na Zona de Amortecimento (SÃO PAULO, 2010). Destacam-se esses dois entraves, entre tantos outros apontados no documento, devido aos conflitos apresentados no planejamento urbano e a conservação do patrimônio natural, principal foco deste trabalho.

O zoneamento de uma UC é um dos instrumentos principais do Plano de Manejo, uma vez que possibilita a organização espacial das zonas em diferentes níveis de proteção, especificações de uso e restrições. A Zona de Amortecimento da EERP tem como objetivo, de acordo com seu Plano de Manejo (SÃO PAULO, 2010):

\begin{abstract}
definir as diretrizes para o ordenamento territorial disciplinando os vetores de pressão negativos no entorno da Estação Ecológica de Ribeirão Preto de forma a proteger e recuperar os mananciais, os remanescentes florestais e a paisagem no entorno da EERP, além de estimular atividades econômicas compatíveis com a manutenção dos processos ecológicos naturais.
\end{abstract}

Para a delimitação da ZA foram consideradas as seguintes ferramentas: mapeamento e interpretação do uso e ocupação das terras; diagnóstico de vetores de pressão urbana sobre a unidade; o Plano Diretor e suas respectivas leis complementares; fragmentos florestais e corpos d'água (SÃO PAULO, 2010). Os dados foram apresentados em reuniões técnicas com participação pública.

Como vetores de pressão urbana foram destacados dois setores distintos de influência sobre a EERP: áreas de alta e média pressão antrópica, que apresentam maior densidade de uso e ocupação do solo (áreas urbanas e de expansão urbana) e as áreas de baixa pressão antrópica, que apresentam relativo grau de conservação ambiental (remanescentes de vegetação nativa e áreas agrícolas). Destaca-se que esses vetores foram caracterizados em 2010 para elaboração do Plano de Manejo (SÃO PAULO, 2010).

Atualmente a Zona de Amortecimento da unidade tem inserção na zona urbana do município, na de expansão urbana e na zona rural (Figura 2). 
Figura 2 - Zona de Amortecimento na Estação Ecológica de Ribeirão Preto

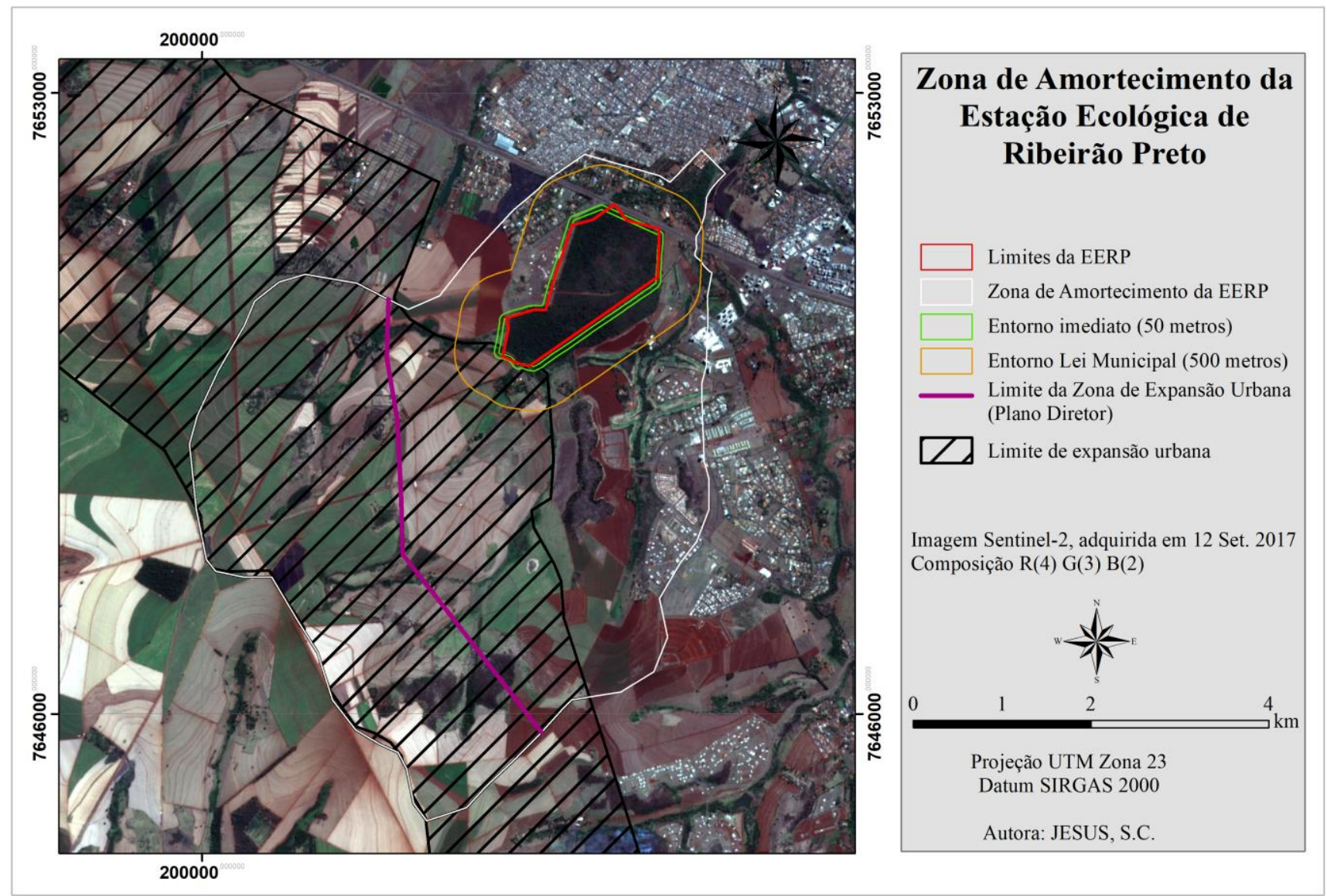

Parte dos limites da Zona de Amortecimento da EERP ocorre sobre locais de relevante potencial hídrico, correspondendo às áreas de nascentes e interflúvio de duas importantes microbacias da região: a da Serraria e a do Horto. Devido a esses aspectos geomorfológicos, o desmatamento dessas microbacias pode vir a contribuir de forma significativa para o assoreamento e enchentes dos rios existentes no município de Ribeirão Preto.

A posição da Zona de Amortecimento também contribui para proteção da bacia hidrográfica do Pardo, sendo referência para o conhecimento científico das espécies nativas para projetos de recuperação de áreas degradadas. A configuração final da Zona de Amortecimento foi concluída com a sua setorização em subzonas, com seus usos definidos de forma a potencializar a sua função ecológica e resguardar áreas mais frágeis (Quadro 1). 
Quadro 1 - Subzonas da Zona de Amortecimento da Estação Ecológica de Ribeirão Preto

\begin{tabular}{|c|c|c|c|c|}
\hline Sub zonas & Função & Delimitação * & Uso permitido & Uso restrito \\
\hline 1 & $\begin{array}{l}\text { Minimizar riscos de } \\
\text { incêndios e } \\
\text { tamponamento de } \\
\text { efeitos poluidores; } \\
\text { Fornecer alimento e } \\
\text { abrigo à fauna } \\
\text { silvestre generalista, } \\
\text { além de preservar a } \\
\text { paisagem, a } \\
\text { visualização da mata } \\
\text { e a conservação da } \\
\text { área natural } \\
\text { legalmente } \\
\text { protegida. }\end{array}$ & $\begin{array}{l}50 \text { m no entorno } \\
\text { imediato em todo } \\
\text { perímetro da EERP, à } \\
\text { exceção da Rodovia SP } \\
322 \text {, onde não haverá } \\
\text { área de tamponamento }\end{array}$ & Não especificado & $\begin{array}{l}\text { Esta área deverá ser } \\
\text { arborizada com } \\
\text { espécies nativas da } \\
\text { bacia hidrográfica do } \\
\text { rio Pardo com } \\
\text { espaçamento entre as } \\
\text { copas das árvores de, } \\
\text { no mínimo, } 4 \mathrm{~m} \text {. Nos } \\
\text { casos de parcelamento } \\
\text { do solo, não será } \\
\text { permitido nenhum tipo } \\
\text { de edificação ou uso } \\
\text { socioeconômico ou } \\
\text { pavimentação, } \\
\text { constituindo-se nas } \\
\text { áreas verdes. }\end{array}$ \\
\hline 2 & $\begin{array}{l}\text { Conservação da área } \\
\text { natural legalmente } \\
\text { protegida, servindo } \\
\text { de trampolins } \\
\text { ecológicos à } \\
\text { avifauna visitante, } \\
\text { manter a } \\
\text { permeabilidade do } \\
\text { solo em taxas } \\
\text { aceitáveis e } \\
\text { preservar a } \\
\text { paisagem e a } \\
\text { visualização da Mata } \\
\text { de Santa Tereza }\end{array}$ & $\begin{array}{l}450 \text { m a partir da } \\
\text { Subzona } 01 \text { da EERP, à } \\
\text { exceção da Rodovia SP } \\
322\end{array}$ & $\begin{array}{l}\text { Estritamente } \\
\text { residencial com } \\
\text { gabarito máximo de } \\
4 \mathrm{~m} \text {, lotes e/ou } \\
\text { unidades residenciais } \\
\text { em condomínios com } \\
\text { área mínima de } 300 \\
\mathrm{~m}^{2} \text { e taxa de } \\
\text { ocupação máxima de } \\
50 \% \text {, sendo que a } \\
\text { densidade bruta da } \\
\text { subzona não poderá } \\
\text { ultrapassar } 100 \\
\text { hab/ha; } \\
\text { Uso agrícola desde } \\
\text { que respeitados os } \\
\text { usos indicados para a } \\
\text { subzona } 04 .\end{array}$ & $\begin{array}{l}\text { As edificações } \\
\text { instaladas na subzona } \\
02 \text { deverão manter } \\
\text { uma taxa de } \\
\text { permeabilidade do solo } \\
\text { de no mínimo } 40 \% \text {, } \\
\text { sendo mínimo de } 20 \% \\
\text { de área comum e } 20 \% \\
\text { nas áreas dos lotes de } \\
\text { modo a manter a } \\
\text { funcionalidade dos } \\
\text { ecossistemas; } \\
\text { Nas áreas de } \\
\text { urbanização } \\
\text { consolidada existentes } \\
\text { após a Rodovia SP } 322 \\
\text { internamente ao anel } \\
\text { viário, será permitida } \\
\text { atividades não } \\
\text { residenciais com índice } \\
\text { e risco ambiental } \\
\text { máximo } 1,0 \text { e ficam } \\
\text { condicionadas ao } \\
\text { licenciamento } \\
\text { ambiental municipal; } \\
\text { O uso de produtos } \\
\text { químicos específicos } \\
\text { será permitido } \\
\text { respeitando-se uma } \\
\text { distância mínima de } 50 \\
\text { m do limite da EERP; } \\
\text { além disto o uso } \\
\text { deverá atender às } \\
\text { normas estabelecidas } \\
\text { em legislação } \\
\text { específica, sendo } \\
\text { obrigatória a }\end{array}$ \\
\hline
\end{tabular}




\begin{tabular}{|c|c|c|c|c|}
\hline Sub zonas & Função & Delimitação * & Uso permitido & Uso restrito \\
\hline & & & & $\begin{array}{l}\text { comunicação da } \\
\text { aplicação à EERP; } \\
\text { As áreas com } \\
\text { vegetação nativa } \\
\text { existentes, } \\
\text { fragmentadas ou } \\
\text { conectadas à EERP, } \\
\text { deverão ser mantidas } \\
\text { podendo constituir a } \\
\text { reserva de áreas } \\
\text { verdes dos } \\
\text { parcelamentos do solo, } \\
\text { conforme Art. } 168 \text { do } \\
\text { Código do Meio } \\
\text { Ambiente de Ribeirão } \\
\text { Preto, Lei municipal } \\
\text { n01616/04. }\end{array}$ \\
\hline 3 & $\begin{array}{l}\text { Manter a } \\
\text { permeabilidade do } \\
\text { solo em níveis } \\
\text { aceitáveis em Zona } \\
\text { de Expansão } \\
\text { Urbana; } \\
\text { Garantir melhor } \\
\text { conectividade da } \\
\text { paisagem e a } \\
\text { proteção da EE; } \\
\text { Preservar a } \\
\text { paisagem, a } \\
\text { visualização da mata } \\
\text { e a conservação da } \\
\text { área natural } \\
\text { legalmente } \\
\text { protegida. }\end{array}$ & $\begin{array}{l}\text { Zona de Urbanização } \\
\text { Controlada de acordo } \\
\text { com Decreto Municipal } \\
\text { de } 2007 \text {, excetuado os } \\
\text { limites das subzonas } 01 \\
\text { e } 02 \text {. }\end{array}$ & $\begin{array}{l}\text { Será admitido uso } \\
\text { misto (residencial e } \\
\text { não residencial), com } \\
\text { índice de risco } \\
\text { ambiental máximo de } \\
1,0 \text {. Serão permitidas } \\
\text { edificações com } \\
\text { gabarito de até } 15 \\
\text { pavimentos, } \\
\text { contados do piso } \\
\text { térreo até o piso do } \\
\text { último pavimento } \\
\text { servido pelo } \\
\text { elevador, desde que } \\
\text { haja um recuo } \\
\text { mínimo de H/3 das } \\
\text { dívidas do lote e no } \\
\text { seu entorno } \\
\text { respeitando no } \\
\text { mínimo, a legislação } \\
\text { vigente. No caso de } \\
\text { mais de um edí́cio } \\
\text { no lote, deverá ser } \\
\text { considerada a altura } \\
\text { do edifício mais alto. } \\
\text { No recuo frontal o } \\
\text { H/32 poderá ser } \\
\text { contado a partir do } \\
\text { eixo da via, } \\
\text { respeitando-se os } \\
\text { recuos previstos na } \\
\text { legislação, de acordo } \\
\text { com a categoria da } \\
\text { via. Quando a } \\
\text { edificação contiver } \\
\text { alturas escalonadas } \\
\text { deverá ser mantida a } \\
\text { restrição de recuo de } \\
\text { H/3 das divisas da } \\
\text { edificação mais alta }\end{array}$ & $\begin{array}{l}\text { As edificações } \\
\text { instaladas na subzona } \\
03 \text { deverão manter } \\
\text { uma taxa de } \\
\text { permeabilidade do solo } \\
\text { de no mínimo } 40 \% \text {, } \\
\text { sendo mínimo de } 20 \% \\
\text { de área comum e } 20 \% \\
\text { nas áreas dos lotes de } \\
\text { modo a manter a } \\
\text { funcionalidade dos } \\
\text { ecossistemas; } \\
\text { Na área de expansão } \\
\text { urbana é obrigatória a } \\
\text { ligação da rede de } \\
\text { esgotos à rede pública, } \\
\text { com tratamento na } \\
\text { ETE pública; } \\
\text { A implantação de } \\
\text { pistas somente será } \\
\text { permitida com redutor } \\
\text { e controle de } \\
\text { velocidade e com } \\
\text { estruturas adequadas } \\
\text { à passagem de fauna } \\
\text { em caso de corredores } \\
\text { ecológicos, além da } \\
\text { previsão de contenção } \\
\text { e infiltração do } \\
\text { deflúvio da via; } \\
\text { Em ZPM expandida } \\
\text { (Lei Municipal } \\
1616 / 04 \text { ) poderão ser } \\
\text { licenciadas medidas } \\
\text { para contenção do } \\
\text { deflúvio, ou seja } \\
\text { barramentos para } \\
\text { regularização da }\end{array}$ \\
\hline
\end{tabular}




\begin{tabular}{|c|c|c|c|c|}
\hline Sub zonas & Função & Delimitação * & Uso permitido & Uso restrito \\
\hline & & & $\begin{array}{l}\text { sendo que o mínimo } \\
\text { deverá ser de } 10 \mathrm{~m} ; \\
\text { A densidade bruta } \\
\text { não poderá } \\
\text { ultrapassar } 300 \\
\text { hab/ha; } \\
\text { Uso agrícola desde } \\
\text { que respeitados os } \\
\text { usos indicados para a } \\
\text { subzona 04; } \\
\text { Nesta subzona, nas } \\
\text { áreas de Zona de } \\
\text { Proteção Máxima } \\
\text { (ZPM) expandidas } \\
\text { constantes do Plano } \\
\text { Diretor do Município } \\
\text { de Ribeirão Preto } \\
\text { serão permitidas } \\
\text { atividades agrícolas, } \\
\text { desde que isentas do } \\
\text { uso de defensivos } \\
\text { agrícolas e não } \\
\text { comprometam a } \\
\text { integridade do meio } \\
\text { físico, da fauna e } \\
\text { flora da microbacia. }\end{array}$ & $\begin{array}{l}\text { vazão, desde que não } \\
\text { alterem a } \\
\text { permeabilidade do solo } \\
\text { e não impliquem em } \\
\text { derrubada da } \\
\text { vegetação arbórea } \\
\text { nativa. }\end{array}$ \\
\hline $3 \mathrm{~A}$ & $\begin{array}{l}\text { Conservar as áreas } \\
\text { vegetadas existentes } \\
\text { na microbacia em } \\
\text { Zona de Urbanização } \\
\text { Controlada, } \\
\text { procurando } \\
\text { estabelecer alguma } \\
\text { conectividade e } \\
\text { ampliar a função da } \\
\text { área natural } \\
\text { legalmente } \\
\text { protegida, além de } \\
\text { manter a } \\
\text { permeabilidade do } \\
\text { solo em limites } \\
\text { aceitáveis em Zona } \\
\text { de Urbanização } \\
\text { Controlada }\end{array}$ & $\begin{array}{l}\text { Faixa de } 500 \mathrm{~m} \text { de } \\
\text { qualquer maciço } \\
\text { florestal de acordo com } \\
\text { o Decreto Municipal de } \\
2007\end{array}$ & $\begin{array}{l}\text { Na faixa de } 10 \mathrm{~m} \\
\text { imediata ao maciço } \\
\text { de vegetação não } \\
\text { será permitido } \\
\text { nenhum tipo de } \\
\text { edificação ou uso } \\
\text { socioeconômico, de } \\
\text { modo a criar um } \\
\text { aceiro de proteção e } \\
\text { esta área poderá ser } \\
\text { considerada nas } \\
\text { reservas de áreas } \\
\text { verdes dos } \\
\text { parcelamentos do } \\
\text { solo. }\end{array}$ & $\begin{array}{l}\text { Na faixa de } 240 \mathrm{~m} \\
\text { imediato ao maciço de } \\
\text { vegetação será } \\
\text { admitido o uso misto } \\
\text { (residencial e não } \\
\text { residencial) com índice } \\
\text { de risco máximo igual } \\
\text { a } 1,0 \text {, gabarito de até } \\
4 \mathrm{~m} \text { (dois pisos) e não } \\
\text { deverá ultrapassar a } \\
\text { densidade bruta de } \\
300 \text { hab/ha; } \\
\text { Na faixa subsequente } \\
\text { de } 250 \mathrm{~m} \text { serão } \\
\text { permitidas edificações } \\
\text { com gabarito de até } \\
10 \mathrm{~m} \text { de altura } \\
\text { (gabarito básico } \\
\text { conforme definido na } \\
\text { LC } 2157 / 07 \text { ) com } \\
\text { afastamento mínimo } \\
\text { entre os edifícios de } \\
10 \mathrm{~m} \text { e } 5 \mathrm{~m} \text { das divisas. } \\
\text { A densidade bruta não } \\
\text { poderá ultrapassar } 300 \\
\text { hab/ha. }\end{array}$ \\
\hline 4 & $\begin{array}{l}\text { Conservar as áreas } \\
\text { de interflúvios e }\end{array}$ & $\begin{array}{l}\text { Microbacia dos córregos } \\
\text { Serraria e do Horto, }\end{array}$ & $\begin{array}{l}\text { Usos agrícolas que } \\
\text { necessitem de }\end{array}$ & Não especificado \\
\hline
\end{tabular}




\begin{tabular}{|c|c|c|c|c|}
\hline Sub zonas & Função & Delimitação * & Uso permitido & Uso restrito \\
\hline & $\begin{array}{l}\text { nascentes que } \\
\text { compõem as } \\
\text { microbacias do } \\
\text { Serraria e do Horto } \\
\text { das quais faz parte } \\
\text { da área da Estação } \\
\text { Ecológica. A par } \\
\text { disso esta região é a } \\
\text { única possibilidade } \\
\text { de se estabelecer } \\
\text { alguma } \\
\text { conectividade e } \\
\text { ampliar a função da } \\
\text { área natural } \\
\text { legalmente } \\
\text { protegida, por meio } \\
\text { da recuperação das } \\
\text { Áreas de } \\
\text { Preservação } \\
\text { Permanente. Esta } \\
\text { conectividade e } \\
\text { permeabilidade } \\
\text { deverá ser capaz de } \\
\text { recuperar a } \\
\text { vegetação e } \\
\text { consequentemente } \\
\text { manter organizado } \\
\text { parte das cadeias } \\
\text { alimentares, } \\
\text { permitindo a } \\
\text { reprodução, a } \\
\text { alimentação e abrigo } \\
\text { a fauna silvestre. }\end{array}$ & $\begin{array}{l}\text { excluídas as subzonas } \\
01,02 \text { e } 03 \text {. }\end{array}$ & $\begin{array}{l}\text { defensivos agrícolas, } \\
\text { poderão fazê-lo } \\
\text { desde que obedeçam } \\
\text { estritamente às } \\
\text { normas de aplicação } \\
\text { e usos de produtos } \\
\text { químicos e não } \\
\text { promovam a deriva } \\
\text { destes produtos para } \\
\text { a área natural } \\
\text { protegida. } \\
\text { Os produtores de } \\
\text { cana-de-açúcar } \\
\text { devem seguir as } \\
\text { diretivas do Protocolo } \\
\text { Agroambiental } \\
\text { Paulista. }\end{array}$ & \\
\hline
\end{tabular}

Fonte: Adaptado do Plano de Manejo da EERP (SÃO PAULO, 2010).

Algumas recomendações quanto à incorporação de práticas conservacionistas na gestão municipal foram feitas no Plano de Manejo, com o objetivo de auxiliar na elaboração e execução de diretrizes. Os critérios de uso foram definidos para as subzonas da Zona de Amortecimento em conjunto com o poder público municipal e devem ser agregados ao Plano Diretor, além das políticas urbana e ambiental do município. Os órgãos licenciadores devem incorporar as recomendações estabelecidas para as subzonas da ZA nos seus termos de referência e respectivas normas reguladoras de atividades sujeitas ao licenciamento ambiental. O Plano de Manejo recomendou, ainda, uma articulação com os órgãos municipal (PMRP) ${ }^{1}$; estaduais (CBRN, DAIA e CETESB) ${ }^{1}$ e

\footnotetext{
${ }^{1}$ PMRP = Prefeitura Municipal de Ribeirão Preto; CBRN = Coordenadoria de Biodiversidade e Recursos Naturais; DAIA = Departamento de Avaliação de Impacto Ambiental; CETESB = Companhia Ambiental do Estado de São Paulo; IBAMA = Instituto Brasileiro do Meio Ambiente e dos Recursos Naturais Renováveis
} 
federal (IBAMA) ${ }^{1}$, para o estabelecimento de procedimentos distintos para o licenciamento nessa zona.

O estabelecimento da Zona de Amortecimento, além de ter como objetivo a mitigação das pressões exercidas sobre a EERP por meio do uso e da ocupação das terras, deve proporcionar uma verificação de alternativas de implementação de políticas públicas que se convertam no planejamento territorial integrado. O incentivo à criação de um sistema de espaços livres, consolidando a criação de corredores verdes com espécies nativas da bacia hidrográfica do rio Pardo e a conservação de remanescentes florestais, pode proporcionar trampolins e corredores ecológicos, impedindo a fragmentação dos ecossistemas (SÃO PAULO, 2010).

Figura 3 - Uso e cobertura das terras na Zona de Amortecimento da EERP (2010)

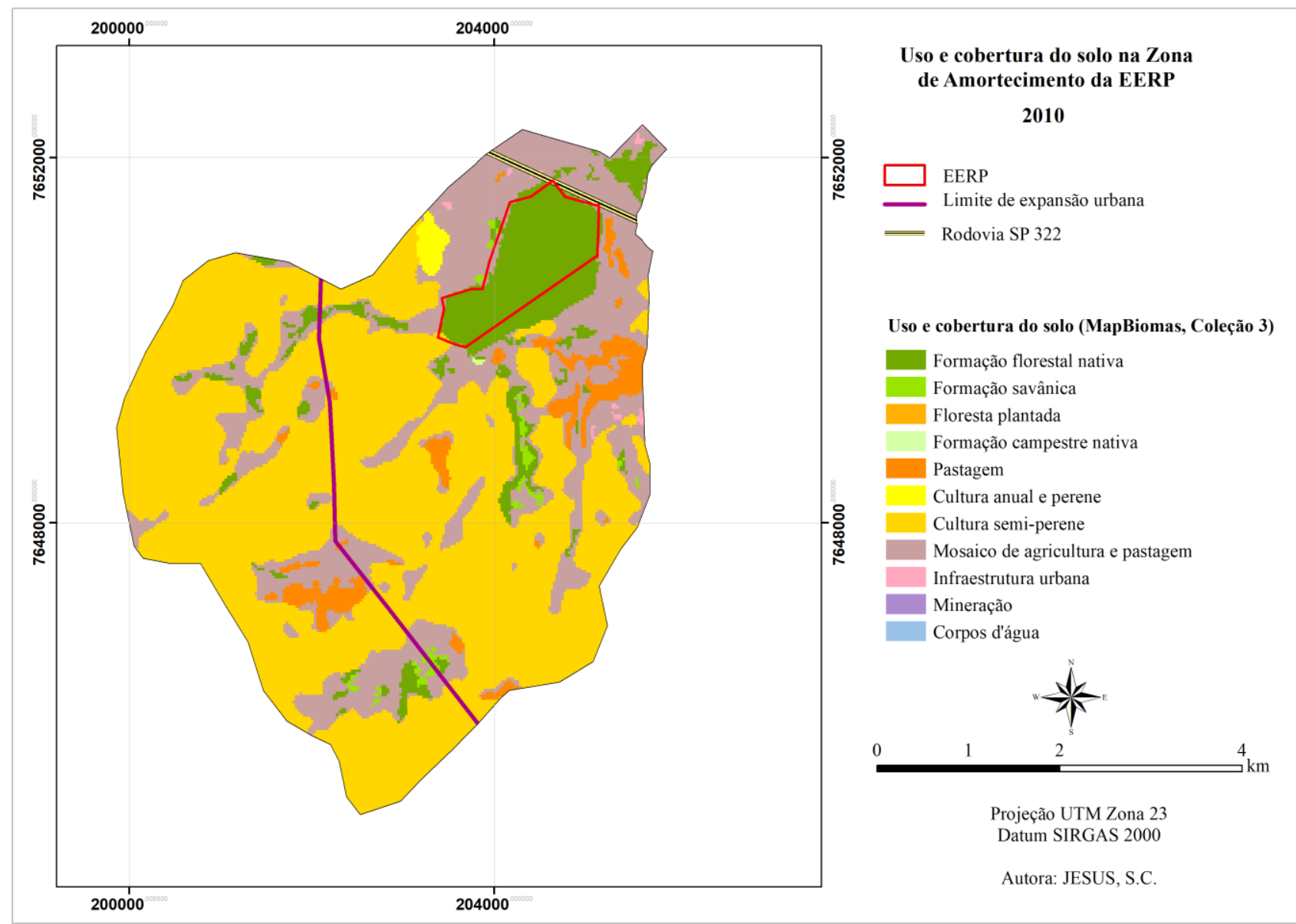

Pela análise dos mapas de uso e ocupação das terras foi possível averiguar quais dessas recomendações foram colocadas em prática tanto pelo poder público municipal quanto pela administração da unidade. O uso e ocupação das terras no ano de 2010 (Figura 03) era regido pela Lei Complementar no 2.157/2007, além do Plano Diretor vigente. Dessa forma, os limites estabelecidos por essas leis foram adotados no Plano de 
Manejo da unidade, publicado em 2010. Nesse período a zona de expansão urbana já abrangia grande parte da Zona de Amortecimento da unidade, sendo o limite da zona urbana estabelecido pela rodovia SP-322.

A Figura 4 mostra os limites estabelecidos no Plano Diretor publicado pela Lei Complementar no 2.866/2018, revogando todos os dispositivos anteriores a ele. Enquanto a Lei de Parcelamento, Uso e Ocupação do solo não foi atualizada, prevista somente para 2019, a definição dos limites da zona urbana e de expansão urbana fica a cargo desse Plano.

Figura 4 - Uso e cobertura das terras na Zona de Amortecimento da EERP (2017)

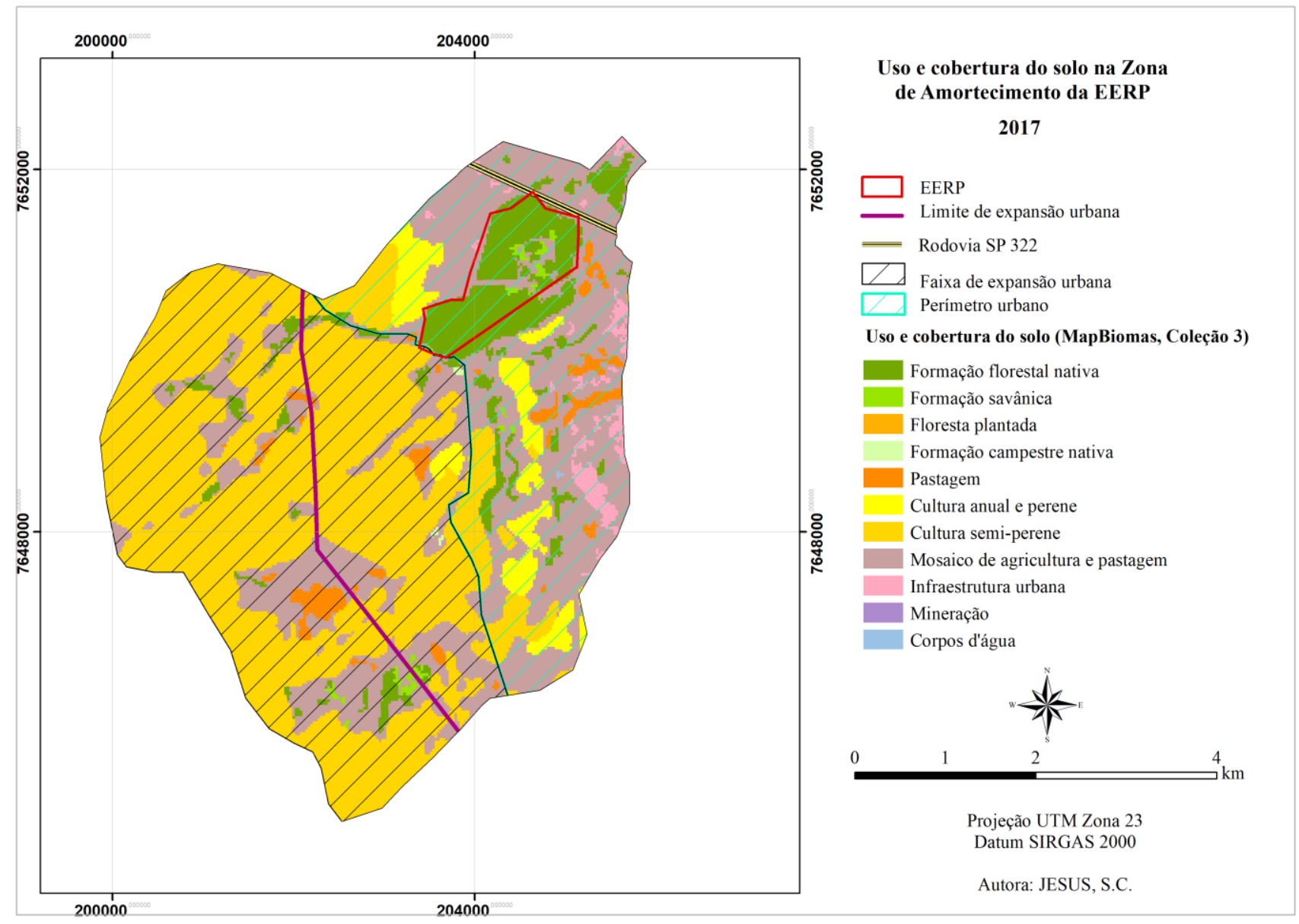

Há um considerável avanço do perímetro urbano, antes limitado pela rodovia e que atualmente envolve grande parte da EERP e parte da ZA. O novo perímetro da zona de expansão urbana também foi ampliado e chega até o limite da unidade. Essa mudança do zoneamento contradiz o que é estipulado pelo SNUC que trata a ZA e as Unidades Conservação de Proteção Integral da seguinte forma: 
Art. 49. A área de uma unidade de conservação do Grupo de Proteção Integral é considerada zona rural, para os efeitos legais. Parágrafo único. A zona de amortecimento das unidades de conservação de que trata este artigo, uma vez definida formalmente, não pode ser transformada em zona urbana (BRASIL, 2000).

As mudanças ocorridas no período de 2010 a 2017 nas classes de uso e ocupação das terras estão apresentadas na Tabela 1.

Tabela 1 - Mudanças na cobertura e uso das terras na EERP e na Zona de Amortecimento da EERP de 2010 a 2017 (área em ha)

\begin{tabular}{lccccccc}
\hline $\begin{array}{l}\text { Mudanças de } \\
\text { cobertura } \\
\mathbf{2 0 1 0}-\mathbf{2 0 1 7} \\
\text { (área em ha) }\end{array}$ & EERP & $\begin{array}{c}\text { Expansão } \\
\text { urbana na } \\
\text { Zona de } \\
\text { Amortecim } \\
\text { ento }\end{array}$ & $\begin{array}{c}\text { Expansão } \\
\text { urbana }\end{array}$ & $\begin{array}{c}\text { Sub-zona } \\
\text { 01 da ZA }\end{array}$ & $\begin{array}{c}\text { Sub-zona } \\
\text { O2 da ZA }\end{array}$ & $\begin{array}{c}\text { Zona de } \\
\text { Amorteci } \\
\text { mento }\end{array}$ & $\begin{array}{c}\text { Total no } \\
\text { município }\end{array}$ \\
\hline $\begin{array}{l}\text { Agropecuária/ } \\
\text { Urbano }\end{array}$ & 0 & 0 & 51 & 0 & 5 & 43 & 1.437 \\
$\begin{array}{l}\text { Agropecuária/ } \\
\text { Vegetação }\end{array}$ & 0 & 14 & 154 & 0 & 5 & 30 & 770 \\
Nativa & 17 & 14 & 138 & 5 & 7 & 41 & 789 \\
$\begin{array}{l}\text { Vegetação } \\
\text { Nativa } \\
\text { /Agropecuária }\end{array}$ & 0 & 0 & 0 & 0 & 0 & 1 & 4 \\
$\begin{array}{l}\text { Vegetação } \\
\text { Nativa/Urbano }\end{array}$ & 137 & 1.700 & 13.366 & 23 & 311 & 2.585 & 64.492 \\
\hline \begin{tabular}{l} 
Inalterado \\
\hline Total
\end{tabular} & 154 & 1.728 & 13.709 & 28 & 328 & 2.699 & 67.493 \\
\hline
\end{tabular}

As culturas semi-perenes, particularmente cana-de-açúcar, são o uso predominante na faixa de expansão urbana na ZA, com algumas áreas de pastagem; eventualmente, estas áreas de pastagem podem ser convertidas em loteamentos reservados para a construção de imóveis. Apesar do prolongamento do limite de expansão urbana, 0 incremento da infraestrutura urbana não ultrapassou a faixa definida no antigo PD, ocupando áreas já antropizadas pela agropecuária.

A cobertura das terras na Estação Ecológica de Ribeirão Preto se manteve praticamente inalterada. No período estudado; 17 hectares de vegetação nativa (11\% da unidade) sofreram impacto antrópico na EERP (Tabela 1), com conversão de área de 
formação florestal nativa para formação campestre; neste caso, trata-se de uma ocorrência de queimada no interior da EERP que deve regenerar como vegetação nativa.

Na Zona de Expansão Urbana ocorreu um incremento de 16 ha de vegetação nativa, uma vez que 138 ha (1\%) foram destinados à agropecuária e 154 ha $(1,12 \%)$ se regeneraram como cobertura vegetal nativa. Dentro da Subzona-2 houve perda de 7 ha da cobertura vegetal nativa ( $2 \%$ desta Zona), pouco menor do que na Subzona 1, onde foram perdidos 5 ha da vegetação nativa (17\% desta Zona). Pelo fato da Subzona-1 ser mais próxima aos limites da EERP e mais estreita, o impacto pode ser proporcionalmente maior. Em relação à Zona de Amortecimento propriamente dita houve a recuperação de 30 ha de vegetação nativa (1\%), em contrapartida, 85 ha (3\%) se tornaram de uso agropecuário ou urbano (Tabela 1).

\subsection{Análise dos Planos Diretores de Ribeirão Preto}

A elaboração do Plano de Manejo da EERP considerou o Plano Diretor vigente em 2010, Lei Complementar no 1.573/2003, e a Lei de Parcelamento, Uso e Ocupação do Solo, Lei Complementar 2157/2007, numa tentativa de compatibilizar o uso do solo urbano no entorno da Unidade e a conservação da biodiversidade. Com objetivo semelhante, a revisão do Plano Diretor em 2018, Lei Complementar n 2.866/2018, criou em seu macrozoneamento urbanístico a Zona de Amortecimento da EERP - Mata de Santa Tereza (ZMT) (Quadro 2).

Quadro 2 - Comparação entre as atualizações do Plano Diretor de Ribeirão Preto com base nos aspectos ambientais

\begin{tabular}{|l|l|l|l|l|}
\hline $\begin{array}{l}\text { Ano do } \\
\text { Plano } \\
\text { Diretor }\end{array}$ & $\begin{array}{c}\text { Lei (s) } \\
\text { correspondente (s) }\end{array}$ & $\begin{array}{l}\text { Principais } \\
\text { aspectos } \\
\text { ambientais }\end{array}$ & $\begin{array}{c}\text { Relação com as UC } \\
\text { urbanas }\end{array}$ & \multicolumn{1}{|c|}{ Zoneamento } \\
\hline $\mathbf{1 9 9 5}$ & $\begin{array}{l}\text { Lei Complementar no } \\
501 / 1995-\text { Plano } \\
\text { Diretor }\end{array}$ & $\begin{array}{l}\text { Possui seção } \\
\text { específica para o } \\
\text { meio ambiente: } \\
\text { Planejamento } \\
\text { ambiental do } \\
\text { município } \\
\text { integrado a todas } \\
\text { as áreas da }\end{array}$ & $\begin{array}{l}\text { Criação de unidades de } \\
\text { Conservação nas áreas de } \\
\text { especial interesse ambiental } \\
\text { e disciplinar, através de } \\
\text { legislação pertinente, o uso e } \\
\text { ocupação do solo nas } \\
\text { imediações das UC, em } \\
\text { faixas e larguras a serem }\end{array}$ & $\begin{array}{l}\text { Zona de Proteção } \\
\text { Máxima (ZPM), } \\
\text { Zona de Uso } \\
\text { Especial (ZUE); } \\
\text { Zona de Uso } \\
\text { Disciplinado (ZUD). }\end{array}$ \\
\hline
\end{tabular}




\begin{tabular}{|c|c|c|c|c|}
\hline & & $\begin{array}{l}\text { administração } \\
\text { municipal }\end{array}$ & $\begin{array}{l}\text { definidas sob critérios } \\
\text { técnicos. } \\
\text { Formação de um sistema de } \\
\text { parque lineares de fundo de } \\
\text { vale e uso agrícola do } \\
\text { mesmo (cinturão verde) }\end{array}$ & \\
\hline 2003 & $\begin{array}{l}\text { Lei Complementar no } \\
\text { 1573/2003 - Revisão } \\
\text { do PD } \\
\text { Lei Complementar no } \\
2157 / 2007 \text { - Lei de } \\
\text { Parcelamento, Uso e } \\
\text { Ocupação do Solo }\end{array}$ & $\begin{array}{l}\text { Inclui o Código de } \\
\text { Meio Ambiente } \\
\text { como um } \\
\text { instrumento de } \\
\text { planejamento, } \\
\text { Fundo Pro Meio } \\
\text { Ambiente como } \\
\text { instrumento } \\
\text { financeiro e } \\
\text { Estudo Prévio de } \\
\text { Impacto } \\
\text { Ambiental e } \\
\text { Estudo de } \\
\text { Impacto de } \\
\text { Vizinhança como } \\
\text { instrumentos } \\
\text { jurídicos e } \\
\text { políticos da } \\
\text { Política Urbana } \\
\text { Municipal. }\end{array}$ & $\begin{array}{l}\text { Anteriormente o Programa } \\
\text { de Dinamização urbana era } \\
\text { constituído de } \\
\text { parque/espaços livres } \\
\text { urbanizados e totalmente } \\
\text { dissociados do contexto da } \\
\text { conservação e preservação } \\
\text { ambiental. Na Revisão de } \\
2003 \text { a criação desses } \\
\text { parques é justificada pelos } \\
\text { "espaços territoriais } \\
\text { especialmente protegidos": } \\
\text { Unidades de Conservação } \\
\text { municipais; Parque urbanos } \\
\text { com caráter de conservação } \\
\text { dos recursos naturais e } \\
\text { recreação da população; } \\
\text { Áreas de Preservação } \\
\text { Permanente; Áreas de } \\
\text { relevante interesse } \\
\text { ecológico; Paisagens notáveis } \\
\text { e Patrimônio arquitetônicos, } \\
\text { histórico-culturais e } \\
\text { paisagísticos. }\end{array}$ & $\begin{array}{l}\text { Zona de } \\
\text { Urbanização } \\
\text { Preferencial (ZUP); } \\
\text { Zona de } \\
\text { Urbanização } \\
\text { Controlada (ZUC); } \\
\text { Zona de } \\
\text { Urbanização } \\
\text { Restrita (ZUR); } \\
\text { Zona Rural (ZR); } \\
\text { Zona de Proteção } \\
\text { Máxima (ZPM); } \\
\text { Zonas de Impacto } \\
\text { de Drenagem } \\
\text { (ZID). }\end{array}$ \\
\hline
\end{tabular}




\begin{tabular}{|c|c|c|c|c|}
\hline 2018 & $\begin{array}{l}\text { Lei Complementar } n^{\circ} \\
2.866 / 2018\end{array}$ & $\begin{array}{l}\text { Compatibilizando } \\
\text { o uso e a } \\
\text { ocupação do solo } \\
\text { com a proteção } \\
\text { do meio ambiente } \\
\text { natural e } \\
\text { construído, } \\
\text { propiciando } \\
\text { melhores } \\
\text { condições de } \\
\text { acesso à terra, à } \\
\text { habitação, ao } \\
\text { trabalho, à } \\
\text { mobilidade } \\
\text { urbana, aos } \\
\text { equipamentos } \\
\text { públicos e aos } \\
\text { serviços urbanos } \\
\text { à população, } \\
\text { evitando-se a } \\
\text { ociosidade dos } \\
\text { investimentos } \\
\text { coletivos em } \\
\text { infraestrutura e } \\
\text { reprimindo a ação } \\
\text { especulativa }\end{array}$ & $\begin{array}{l}\text { A Zona de Amortecimento da } \\
\text { Estação Ecológica de } \\
\text { Ribeirão Preto foi } \\
\text { incorporada ao } \\
\text { macrozoneamento } \\
\text { urbanístico. Corresponde à } \\
\text { área localizada no entorno da } \\
\text { Estação Ecológica, onde a } \\
\text { urbanização está sujeita a } \\
\text { normas que visam preservar } \\
\text { a paisagem e o ecossistema } \\
\text { existentes (dentro do } \\
\text { macrozoneamento } \\
\text { urbanístico/dentro do } \\
\text { perímetro urbano). É } \\
\text { compatível com o que foi } \\
\text { estabelecido no Plano de } \\
\text { Manejo da unidade. }\end{array}$ & $\begin{array}{l}\text { I - } \\
\text { Macrozoneament } \\
\text { o Ambiental: } \\
\text { Zona de Uso } \\
\text { Disciplinado (ZUD); } \\
\text { Zona de Uso } \\
\text { Especial (ZUE); } \\
\text { Zonas de Proteção } \\
\text { Máxima (ZPM). } \\
\text { II - } \\
\text { Macrozoneament } \\
\text { o urbanístico: } \\
\text { Zona de } \\
\text { Urbanização } \\
\text { Preferencial (ZUP); } \\
\text { Zona de } \\
\text { Urbanização } \\
\text { Controlada (ZUC); } \\
\text { Zona de } \\
\text { Urbanização } \\
\text { Restrita (ZUR); } \\
\text { Zona de } \\
\text { Amortecimento da } \\
\text { Estação Ecológica } \\
\text { de Ribeirão Preto - } \\
\text { Mata de Santa } \\
\text { Tereza (ZMT); Zona } \\
\text { de Proteção } \\
\text { Máxima (ZPM); As } \\
\text { Zonas Especiais de } \\
\text { Rural (ZR). } \\
\text { Interesse Social } \\
\text { (Z); Zona } \\
\text { ZEI }\end{array}$ \\
\hline
\end{tabular}


$\mathrm{Na}$ análise do conteúdo dos Planos Diretores e suas respectivas leis complementares, observou-se uma tendência de incorporação de conceitos relacionados ao meio ambiente urbano. A consolidação do licenciamento ambiental no nível local, com a publicação da Lei Complementar no 140/2011, ao modificar o Artigo 23 da Constituição Federal, colocou os municípios de todo o país como atores chave na gestão ambiental do seu território. Porém, entraves têm dificultado a consolidação da política ambiental nesses municípios, rompendo a expectativa criada com a aproximação do poder público dos problemas ambientais locais (ABREU; FONSECA, 2017; NASCIMENTO et al, 2020).

"O acirramento das pressões pela flexibilização de restrições sobre áreas de proteção ambiental é foi também explicitado pelo significativo número de autorizações para intervenções em áreas de interesse ambiental" (ARAÚJO, 2011).

\section{CONSIDERAÇÕES FINAIS}

As Unidades de Conservação urbanas representam, em sua maioria, a resistência de remanescentes de vegetação natural nos municípios brasileiros. Apesar de sua reconhecida importância para o clima e a saúde e bem-estar dos moradores das cidades, ainda ocorre a sobreposição dos interesses do mercado em detrimento da população local. Ainda se observa o aumento das pressões pela flexibilização do uso e ocupação em áreas de proteção ambiental e seu entorno. Situação semelhante foi encontrada na Estação Ecológica de Ribeirão Preto e sua respectiva Zona de Amortecimento.

A urbanização no entorno da EERP torna a unidade mais vulnerável do que se esta estivesse envolvida em um ambiente menos antropizado. A parte do perímetro da EERP em que a ZA é mais estreita e tange a malha urbana, intensifica os efeitos de borda na unidade. Pela análise de dados de cobertura do solo dos anos 2010 e 2017, pode-se observar uma latente pressão da expansão urbana sobre a zona de amortecimento e uma contínua fragmentação da sua vegetação original. Esse processo de avanço da área urbana possui respaldo legal, como é possível notar nas mudanças sobre o zoneamento nas revisões do Plano Diretor, especialmente na sua última atualização, no ano de 2018, que insere toda a EERP e sua Zona de Amortecimento na área urbana ou de expansão urbana. Apesar de encontrar-se altamente antropizada, com áreas de pastagem, de culturas antrópicas e aumento da infraestrutura urbana, a ZA da EERP ainda se apresenta como uma importante zona tampão, que disciplina de maneira mais restritiva o uso e 
ocupação das terras na tentativa de impedir que impactos negativos atinjam a área da unidade.

Ressalta-se a importância da gestão integrada e participativa da EERP, com atuação das governanças e das comunidades locais, que devem compreender a importância da manutenção da UC inserida no espaço urbano. As transformações da paisagem no entorno da EERP devem ser conduzidas de forma a seguir o propósito da ZA, especialmente por tratar-se de uma UC de Proteção Integral.

Regularmente os impactos ecológicos cumulativos do uso e ocupação das terras são ignorados nas decisões locais de planejamento. Um fator que contribui para fragilizar as questões ambientais é o fato do planejamento do uso e ocupação das terras e os recursos naturais serem, frequentemente, administrados por diferentes agências e/ou níveis de governo.

Os vetores de pressão urbana identificados no Plano de Manejo da EERP representam a realidade da maioria dos municípios brasileiros. Nos conflitos entre meio ambiente e parcelamento do solo, os mercados imobiliário e financeiro acabam por fazer valer seus interesses. Dessa forma, as informações dispostas no PM vigente tornam-se conflitantes com as leis municipais atuais, uma vez que o plano adota leis municipais já revogadas. Sendo assim, é importante que o PM passe por processo de revisão, como determina o SNUC e, uma vez que a Lei de Uso e Ocupação do Solo está sendo revisada e o PD vigente já mostra as mudanças no parcelamento do solo, os órgãos competentes para a elaboração desses documentos devem convergir no sentido de cumprir com os preceitos do Artigo 225 da $\mathrm{CF} / 88$.

A transposição de certas lógicas e a apresentação de formas de ocupação mais equitativas pela perspectiva socioambiental requer, consequentemente, novos compromissos pela gestão pública municipal, além de novas dinâmicas de participação social diante dos atuais sistemas urbanos. Dessa forma, é fundamental um maior aparelhamento dos órgãos ambientais e urbanísticos de Ribeirão Preto e uma melhor comunicação destes com a sociedade civil, facilitando e ampliando a participação popular nos processos de planejamento e gestão urbano-ambiental e da conexão de políticas públicas, priorizando os interesses coletivos e as funções sociais e o direito à cidade em primeiro plano. 


\section{REFERÊNCIAS}

ABREU EL, FONSECA A. Análise comparada da descentralização do licenciamento ambiental em municípios dos estados de Minas Gerais e Piaú. Sustentabilidade Em Debate. 2017;8(3):167-180. DOI: https://doi.org/10.18472/SustDeb.v8n3.2017.21891.

ABREU EL, SANTILI CA, PERES RB. Regulação e aplicação do Estudo de Impacto de Vizinhança (EIV) no município de Jundiaí-SP. In: X Congresso Brasileiro de Gestão Ambiental. Fortaleza; 2019. 1-9. [cited 2020 fev 01] Avaliable from: http://www.ibeas.org.br/congresso/Trabalhos2019/V-054.pdf.

BEIROZ H. Zonas de amortecimento de Unidades de Conservação em ambientes urbanos sob a ótica territorial: reflexões, demandas e desafios. Desenvolv. Meio Ambient. 2015; 35:275-286.

BENJAMIN AH. O regime brasileiro de unidades de conservação. Rev. Dir. Ambient. 2001; 21:27-49.

BRASIL; Lei Federal no 9.985, de 18 de julho de 2000 - Institui o Sistema Nacional de Unidades de Conservação da Natureza e dá outras providências. Diário Oficial da União. De julho de 2000. Disponível em: http://www.planalto.gov.br/ccivil_03/LEIS/L9985.htm. Acesso em:18 dez. 2018.

BRITO DMC. Conflitos em unidades de conservação. PRACS: Rev. Eletrônica de Humanidades do Curso de Ciências Sociais da UNIFAP. 2008; 1(1)1-12.

COSTA HS de M.; PEIXOTO MCD. Dinâmica imobiliária e regulação ambiental: uma discussão a partir do eixo-sul da Região Metropolitana de Belo Horizonte. Rev. Bras. Estud. Popul. 2007; 4(2):317-336.

DIEGUES ACS. O mito moderno da natureza intocada. São Paulo: Hucitec; 1996.

GOMES LJ, CARMO MD, SANTOS RD. Conflitos de interesses em Unidades de Conservação do município de Parati, Estado do Rio de Janeiro. Infor. Econ. 2004; 34(6):17-27.

GOULART JO, BENTO PP. Enclaves fortificados e segregação urbana: o caso de Jundiaí. Soc. e Cult. 2011; 14(1):181-193.

HARVEY D. Cidades rebeldes: do direito à cidade à revolução urbana. São Paulo: Martins Fontes; 2014.

INSTITUTO BRASILEIRO DE GEOGRAFIA E ESTATÍSTICA [Internet]. Brasília: Ministério do Planejamento, Orçamento e Gestão (BR) [cited 2018 out 01]. Censo 2010. Available from: https://cidades.ibge.gov.br/brasil/sp/ribeirao-preto/panorama.

INSTITUTO BRASILEIRO DE GEOGRAFIA E ESTATÍSTICA [Internet]. Ministério da Economia. Manual Técnico de Uso da Terra. Brasília (Brasil): Ministério da Economia, 2013. [cited 2018 out 01]. Available from: https://biblioteca.ibge.gov.br/visualizacao/livros/liv81615.pdf. 
KOTCHETKOFF-HENRIQUES $O$ et al. Relação entre o solo e a composição florística de remanescentes de vegetação natural no Município de Ribeirão Preto, SP. Rev. Bras. Bot, 2005; 28(3):541-562.

KRIPKA R M L, SCHELLER M, BONOTTO D L. Pesquisa documental: considerações sobre conceitos e características na pesquisa qualitativa. VI Simpósio Internacional de Educação e Comunicação. Atas CIAIQ2015. 2015; 2:243-247.

KUDO S A, PEREIRA H dos S; SILVA S C P. A proteção jurídica dos fragmentos florestais urbanos: um estudo da paisagem e da legislação ambiental e urbanística da cidade de Manaus. Desenvolv. Meio Ambient. 2016; 38:521-540.

MAPBIOMAS [Internet]. Brasil: MapBiomas [cited 2018 nov 19]. Projeto MapBiomas Coleção 3.0 da Série Anual de Mapas de Cobertura e Uso de Solo do Brasil. Available from: https://code.earthengine.google.com/.

MAZZEI K, COLESANTI MTM, SANTOS DG. Áreas verdes urbanas, espaços livres para o lazer. Soc. \& Nat. 2007; 19(1):33-43.

MORAES MCP, MELLO K, TOPPA RH. Análise da paisagem de uma zona de amortecimento como subsídio para o planejamento e gestão de unidades de conservação. Rev. Árvore. 2015; 39(1):1-8.

NASCIMENTO T, ABREU EL, FONSECA A. Decentralization of Environmental Licensing and Impact Assessment in Brazil: Literature and Regulatory. Ambient e Soc. 2020; 23:1-22. DOI: https://doi.org/10.1590/1809-4422asoc20180266r2vu2020l1ao.

NESPOLO CCC, ABREU EL, VICENTE CP, PERES RB. Planos Diretores de Arborização Urbana: Necessidade de incorporação na legislação brasileira. Revista da Sociedade Brasileira de Arborização Urbana. 2020;15(2):42-55. DOI: http://dx.doi.org/10.5380/revsbau.v15i2.70466

PARFITT CM. Áreas de preservação do ambiente natural urbano, segregação e impacto nas paisagens e na biodiversidade: estudo de caso de Pelotas RS. Raega. 2016; 37:07-36.

PECCATIELLO AFO. Políticas públicas ambientais no Brasil: da administração dos recursos naturais (1930) à criação do Sistema Nacional de Unidades de Conservação (2000). Desenvolv. Meio Ambient. 2011; (24):71-82.

PERES RB, CASSIANO AM. O Estudo de Impacto de Vizinhança (EIV) nas regiões Sul e Sudeste do Brasil: avanços e desafios à gestão ambiental urbana. Urbe Rev Bras Gestão Urbana. 2019; 11:1-15. DOI: 10.1590/2175-3369.011.e20180128.

PERES RB, SILVA RS. Interfaces da gestão ambiental urbana e gestão regional: análise da relação entre Planos Diretores Municipais e Planos de Bacia Hidrográfica. Rev. Bras. Gest. Urb. 2013;5(2):13-25.

ROLNIK R. Guerra dos lugares: a colonização da terra e da moradia na era das finanças. 1st ed. São Paulo: Boitempo; 2015.

ROLNIK R. Plano Diretor Participativo. Guia para elaboração pelos municípios e cidadãos. Brasília: Ministério das Cidades, 2004. 
SALLES MCT, GRIGIO AM, SILVA MRF. Expansão urbana e conflito ambiental: uma descrição da problemática do município de Mossoró, RN-Brasil. R. Soc. \& Nat. 2013; 25(2):281-290.

SÃO PAULO/SMA - Instituto Florestal (IF). Plano de Manejo da Estação Ecológica de Ribeirão Preto. Secretaria de Estado do Meio Ambiente de São Paulo, 2010. [cited 2018 out 01$]$. Available from: http://arquivos.ambiente.sp.gov.br/fundacaoflorestal/2012/01/EERP-Vol-principal.pdf

VARANDA EM et al. Áreas prioritárias ao restabelecimento da conectividade estrutural entre fragmentos florestais da zona de amortecimento da Estação Ecológica de Ribeirão Preto. Rev. Inst. Flor. 2015; 27(1):49-71. 